\title{
Heavy Metals' Concentration in Textile and Garments Industries' Wastewater of Bhaluka Industrial Area, Mymensingh, Bangladesh
}

\section{BIDDUT CHANDRA SARKER ${ }^{*}$, MD. ABDUL BATEN ${ }^{1}$, MD. EKRAM UL HAQUE ${ }^{2}$, ALOK KUMAR DAS ${ }^{3}$, AHMED HOSSAIN ${ }^{4}$ and MD. ZAHEDUL HASAN ${ }^{1}$}

\author{
${ }^{1}$ Department of Environmental Science, Bangladesh Agricultural University, \\ Mymensingh-2202, Bangladesh. \\ ${ }^{2}$ Soil Science Division, Bangladesh Institute of Nuclear Agriculture (BINA), \\ Mymensingh-2202, Bangladesh. \\ ${ }^{3}$ Department of Environmental Science and Resource Management, \\ Mawlana Bhashani Science and Technology University, Tangail-1902, Bangladesh. \\ ${ }^{4}$ Department of Biotechnology, Bangladesh Agricultural University, Mymensingh-2202, Bangladesh. \\ http://dx.doi.org/10.12944/CWE.10.1.07 \\ (Received: November 28, 2014; Accepted: January 29, 2015)

\begin{abstract}
An investigation was made to ascertain heavy metals' concentration in effluent samples collected from different textile and garments industries located in Bhaluka industrial area, Mymensingh, Bangladesh during August to November, 2013. Atomic Absorption Spectrometer (AAS) was used to evaluate concentration of Zinc (Zn), Copper (Cu), Nickel (Ni), Cadmium (Cd), Chromium $(\mathrm{Cr})$ and Lead $(\mathrm{Pb})$ in the samples. The study revealed that heavy metals were present in variable amounts, where concentrations of $\mathrm{Cu}(0.0405 \mathrm{ppm})$ and $\mathrm{Pb}(0.0003 \mathrm{ppm})$ were found lower than recommended level for industrial wastewater. Among the present trace metals, the highest concentration (0.2-1.0 ppm) was found in $\mathrm{Zn}$. Although the concentration was suitable for irrigation, it was unsafe for aquaculture. Besides, all of the wastewater samples possessed no $\mathrm{Cr}, \mathrm{Cd}$ and $\mathrm{Ni}$, which indicated no possibility of contamination by these metals. However, comparing findings of this study with the safe limits for industrial wastewater, it was concluded that the wastewater of the whole study area except that of some sampling sites could be used for irrigation and aquaculture.
\end{abstract}

Key words: Atomic Absorption Spectroscopy (AAS), Contamination, Discharge, Heavy metals, Industrial wastewater.

\section{INTRODUCTION}

In the modern world, environmental pollution has been recognized as one of the major problems. The activities of human society influence biogeochemical cycles via industries and have led to various irreversible changes in our environment ${ }^{1,2}$. As a result, undesirable effects of poor environmental circumstances on human health are mostly manifested in environment, predominantly in developing countries where urbanization, industrialization and rapid population growth are taking place on an unprecedented scale ${ }^{3-5}$.

The irregular disposal of industrial wastes has created pollution problems since this waste is disseminated in the environment or is accumulated in sediments, aquatic organisms, and water ${ }^{6}$. Majority of manufacturing processes are water based and a considerable volume of effluent is ejected to the environment in either treated or inadequately treated form, leading to surface and groundwater 
pollution ${ }^{7}$. Industries have contributed to serious and widespread deterioration in the quality of water, land and air in Bangladesh ${ }^{8}$. Textile is the most important sector of Bangladesh's economy that utilizes a large quantity of water in production process and consequently highly polluted and toxic wastewaters are discharged into sewers and drains without any kind of treatment ${ }^{9}$. Textile and Garments' washing \& dyeing sections have been condemned as being one of the world's most offenders in terms of pollution ${ }^{10}$. Textile industries are major sources of pollution and contributors of metal contaminants to the environment. Although most of the industries are supposed to have effluent treatment plant, however, so far only a few industries have implemented it, although treatment alternatives are either; complex, energy consuming, expensive or applicable to an indisputable portion of the world due to proficient work force requirement ${ }^{7}$. A large number of factories are operating without the ETPs, violating existing laws ${ }^{11}$. Heavy metals are natural components of the earth's crust. They cannot be degraded or destroyed. Today, contamination of water by toxic heavy metals in the form of effluents from industries is a worldwide environmental problem. To a small extent they enter our bodies via food, drinking water and air. As trace elements, some heavy metals (e.g. lead, chromium, copper, mercury, manganese, selenium, zinc etc) are essential to maintain metabolism of human body. However, at higher concentrations they can lead to poisoning ${ }^{12}$. Effluents discharged from textiles contain a higher amount of metals. These effluents are released on the land as well as discharged into the surface water which ultimately end up in groundwater by leaching and lead to contamination of it due to accumulation of toxic metallic components ${ }^{13}$. Thus industrial effluents induce a wide range of environmental problems, more complex and critical health hazards in developing countries like Bangladesh as well as other developed countries. Industrial effluent is a major source of direct and often continuous input of pollutants into aquatic ecosystems with long-term implications on ecosystem functioning ${ }^{14-17}$. Keeping these facts in mind, therefore, the present study was undertaken to assess heavy metal concentrations of wastewater dumping site in Bhaluka industrial area, Mymensingh, Bangladesh.

\section{MATERIALS AND METHODS}

\section{Study Area}

Textile and garments industries, situated in Habirbari union of Bhaluka upazila, "Mymensingh district" located approximately within latitude at $24.3750^{\circ} \mathrm{N}$ and longitude at $90.3778^{\circ} \mathrm{E}$ (Fig. 1) were selected to evaluate heavy metal concentration in effluents.

\section{Sample collection}

The industrial effluent's samples (E1-E12) were collected during September 2013 from effluent discharging drains originated from six different industries' outlet. The sampling points (S1-S12) were designed in relation to industries as depicted by Fig. 2. Samples were preserved for laboratory analysis maintaining with proper direction.

\section{Analytical procedures: determination of heavy metals}

Determination of different heavy metals viz. $\mathrm{Zn}, \mathrm{Cu}, \mathrm{Ni}, \mathrm{Cd}, \mathrm{Cr}$ and $\mathrm{Pb}$ in water samples was done by an Atomic Absorption Spectrophotometer (AAS) (Varian Spectra AA55B, Australia) as suggested by APHA ${ }^{19}$. A standard line was prepared by plotting the absorbance reading on $\mathrm{Y}$-axis versus the concentration of each standard solution of metal on $X$-axis. The concentration of metal was calculated by putting AAS reading on the standard line.

\section{Data analysis}

Descriptive statistical parameters were calculated with SPSS software package and Microsoft Office Excel. Various descriptive statistical measures such as range, number, percentage, mean, standard deviation (SD), etc were used for categorization and describing the variables.

\section{RESULTS AND DISCUSSION}

\section{Heavy metal concentrations}

Descriptive statistics of the data including wastewater parameters of six metal concentrations are shown in Table 1. Among the studied heavy metals the most dominant metal was $\mathrm{Zn}$ followed by $\mathrm{Cu}, \mathrm{Cd}, \mathrm{Pb}, \mathrm{Cr}$ and $\mathrm{Ni}$. Distinct variation was observed among heavy metal contents in the effluent samples. The amount of $\mathrm{Cu}$ varied from 0 to 0.356 
ppm (Table 1), with an average value of 0.0405 ppm, which indicated that this effluent could be safely used for irrigation as well as other purposes in respect of $\mathrm{Cu}$ concentration. Among all samples, 11 samples were found within the recommended limit except $\mathrm{E} 6$, for irrigation where its acceptable limit is 0.20 $\mathrm{ppm}^{20}$.

Concentration of $\mathrm{Zn}$ varied from 0.2 to $1 \mathrm{ppm}$ where the mean was 0.512 ppm (Table 1) and standard deviation was 0.208. The highest concentration (1.0 ppm) was found at the point $\mathrm{E} 6$ and the lowest concentration (0.2 ppm) was observed at E12. A nearly similar Zn concentration was recorded at E5 (0.65 ppm), E9 (0.64 ppm) and E11 (0.65 ppm) and same (0.34 ppm) in E4 and E8. According to Ayers and Westcot ${ }^{20}$, the maximum permissible limit of $\mathrm{Zn}$ in irrigation water is 2.00 ppm. Comparing to standard limits, in respect of $\mathrm{Zn}$, all effluent samples were found as suitable for

Table 1: Available concentration of the heavy metals in samples $\left(E_{1}-E_{12}\right)$ where, $n=12$

\begin{tabular}{lccc}
\hline \multirow{2}{*}{ Metals } & \multicolumn{3}{c}{ Descriptive statistics } \\
\cline { 2 - 4 } & Minimum* $^{*}$ & Maximum* & Mean* $^{\star}$ SD \\
\hline Cadmium (Cd) & 0.00 & 0.00 & $0.00 \pm 0.00$ \\
Copper (Cu) & 0.00 & 0.356 & $0.0405 \pm 0.10$ \\
Chromium (Cr) & 0.00 & 0.00 & $0.00 \pm 0.00$ \\
Lead (Pb) & 0.00 & 0.002 & $0.0003 \pm 0.0006$ \\
Zinc $(\mathrm{Zn})$ & 0.20 & 1.00 & $0.512 \pm 0.208$ \\
Nickel $(\mathrm{Ni})$ & 0.00 & 0.00 & $0.00 \pm 0.00$ \\
\hline
\end{tabular}

\section{Note: $\mathrm{SD}=$ Standard deviation; ${ }^{*}=\mathrm{ppm}$}
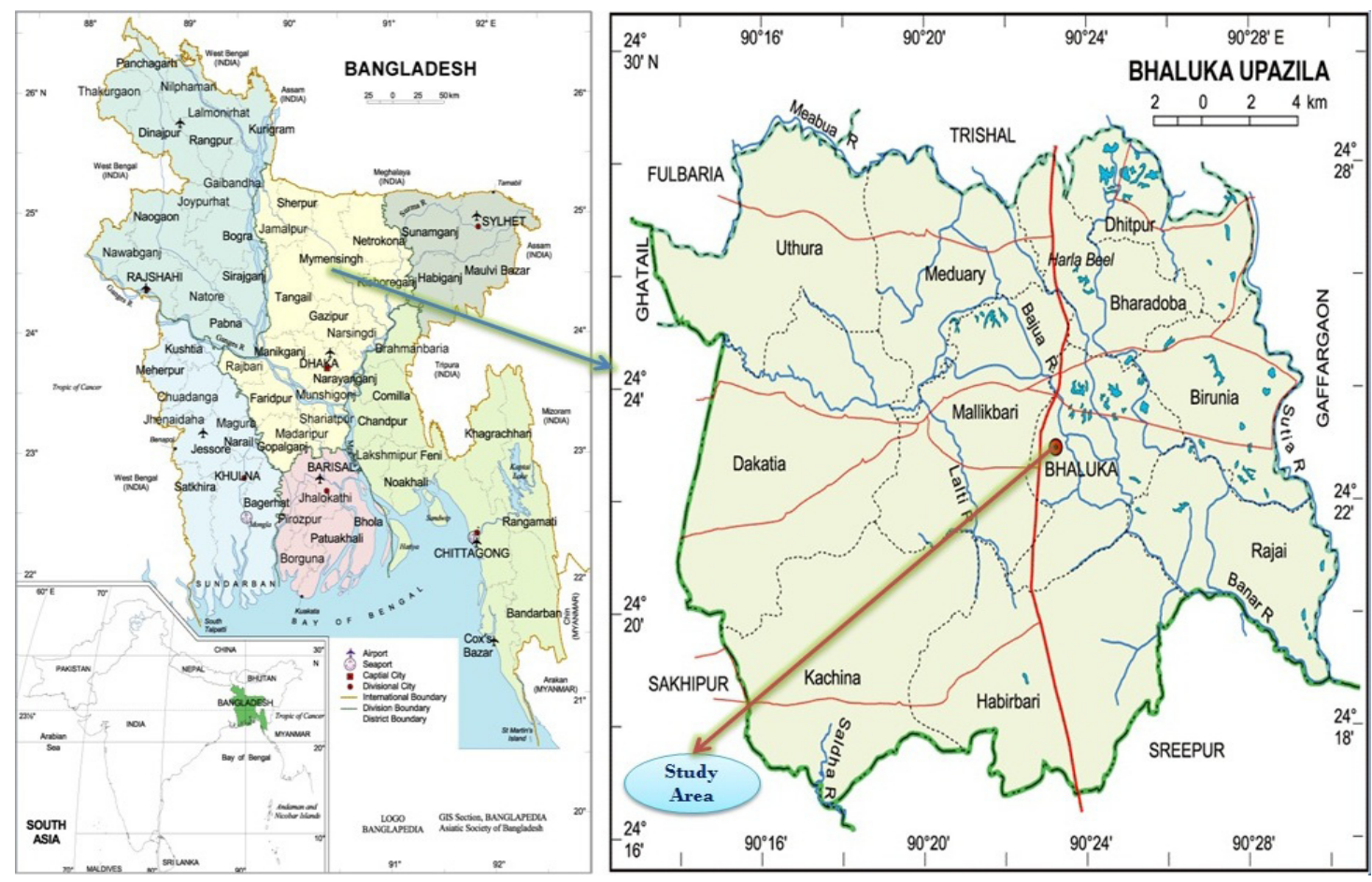

Fig. 1: Map showing the study area ${ }^{18}$ 
irrigation ${ }^{21}$ but exceeded the standard value for aquaculture $^{22}$. Therefore, the water was harmful for aquatic life and thus unsuitable for aquaculture. The degree of relationship between available $\mathrm{Zn}$ content and $\mathrm{Cu}$ (Fig. 3) of the samples revealed that the strongest positive correlation existed between $\mathrm{Zn}$ and $\mathrm{Cu}$ at $5 \%$ level (2-tailed) of significance where the correlation value $(r)=0.707^{\star}$.

Concentration of $\mathrm{Pb}$, ranging from 0 to $0.002 \mathrm{ppm}$ with an average value of $0.0003 \mathrm{ppm}$ and standard deviation of 0.00065 indicated that the analyzed effluents were free from lead $(\mathrm{Pb})$ contamination $^{20}$ and thus suitable for irrigation ${ }^{21}$ and aquaculture $^{22}$. Correlation between concentration of available $\mathrm{Cu}, \mathrm{Pb}$ (Fig. 4) and $\mathrm{Zn}, \mathrm{Pb}$ (Fig. 5) of the water samples had a negative relationship where the correlation values $(r)$ were 0.158 and 0.0447 , respectively.

Experimental result also revealed that $\mathrm{Cr}$, $\mathrm{Cd}$ and $\mathrm{Ni}$ were found as trace amount in effluent samples (Table 1), leading to the decision that the samples were free from Chromium, Cadmium ${ }^{23}$ and

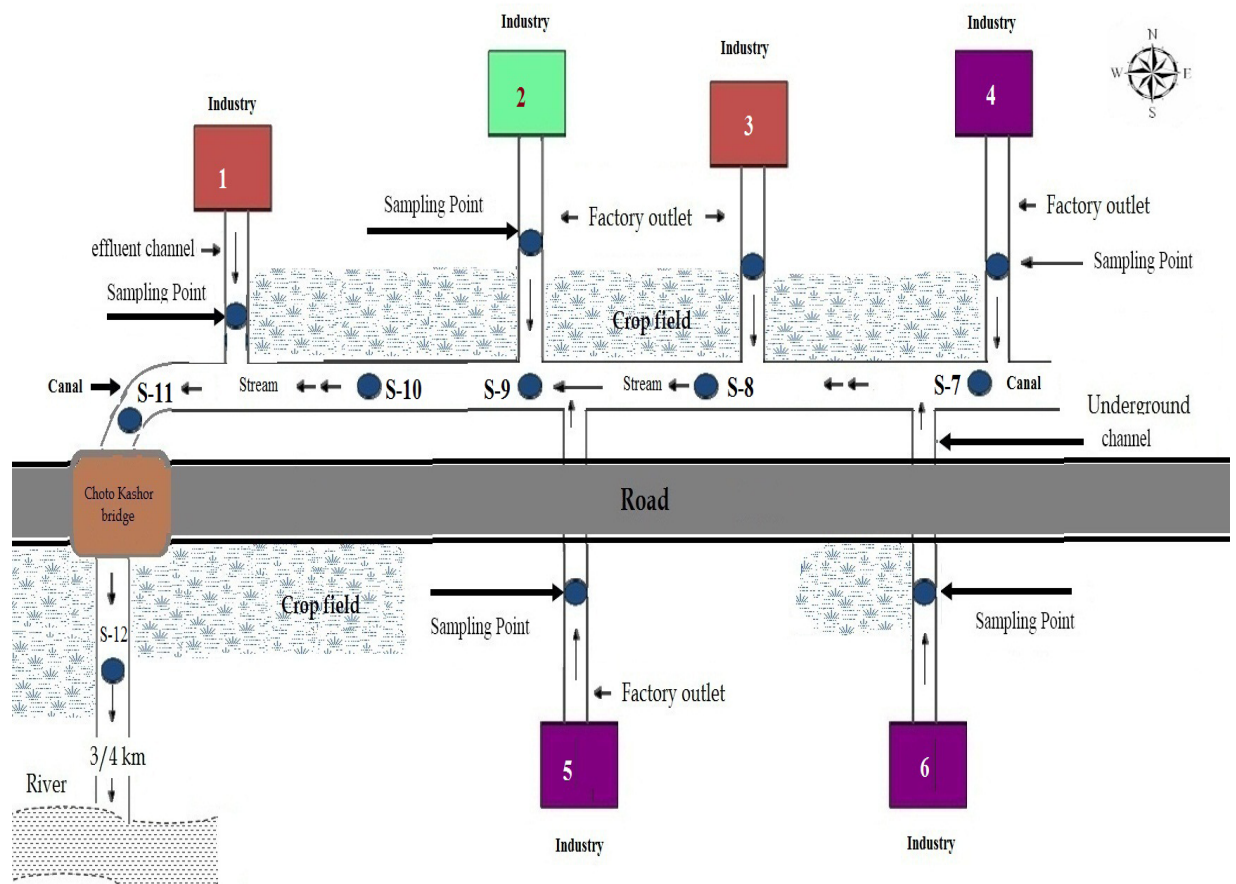

Fig. 2: A sketch map representation of the selected sampling sites

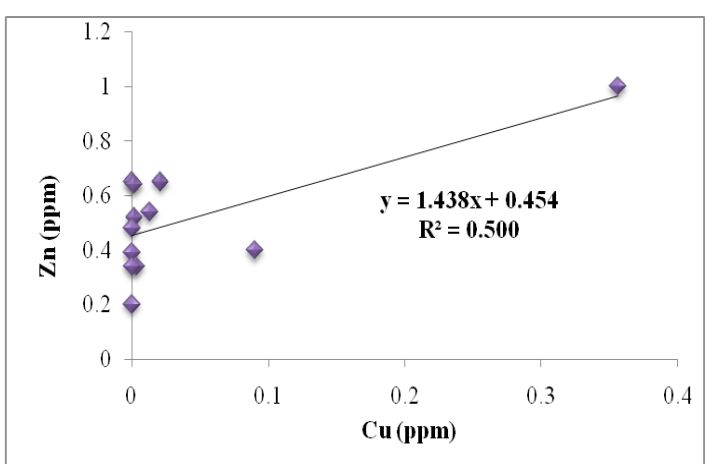

Fig. 3: Correlation between $\mathrm{Zn}$ and $\mathrm{Cu}$

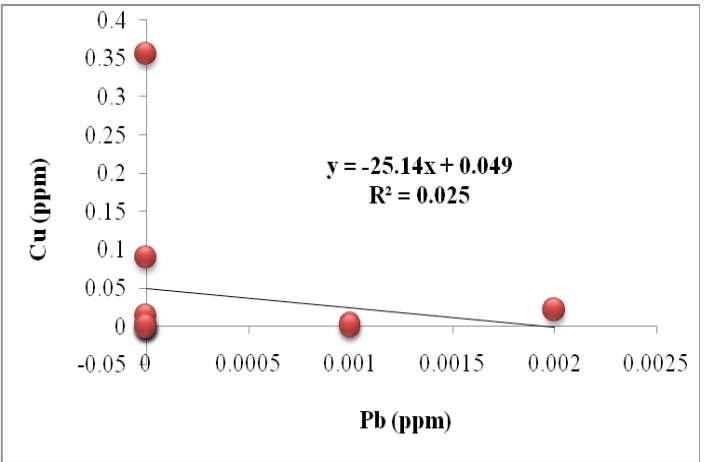

Fig. 4: Correlation between $\mathrm{Cu}$ and $\mathrm{Pb}$ 


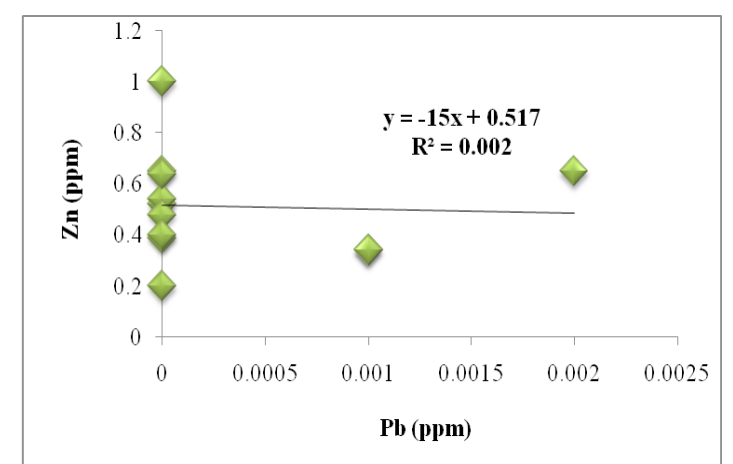

Fig. 5: Correlation between $\mathrm{Zn}$ and $\mathrm{Pb}$

Nickel contamination.

\section{CONCLUSION}

On the basis of results of the experiment it can be stated that level of heavy metal contamination in collected wastewaters from textile and garments industries was generally low and showed an acceptable limit. The objectionable appearance of canal water could be attributed to the discharge of untreated industrial wastewaters. Though some of the chemical elements were beneficial for agriculture and aquaculture up to a certain limit, it might be potentially detrimental beyond that.

\section{ACKNOWLEDGEMENTS}

The authors are thankful to the personnel of Soil Science division, Bangladesh Institute of Nuclear Agriculture (BINA), Mymensingh, Bangladesh, for providing necessary support during study period.

\section{REFERENCES}

1. Khairiah J., Ding-Woei Y., Habibah J., Ahmad-Mahir R., Aminah A. and Ismail B.S., Concentration of Heavy Metals in Guava Plant Parts and Soil in the Sungai Wangi Plantation, Perak, Malaysia. International Journal Agriculture Research, 4: 310-316 (2009).

2. Cheraghi M., Lorestani B. and Yousefi N., Effect of Wastewater on Heavy Metal Accumulation in Hamedan Province Vegetables. International Journal of Botany, 5: 190-193 (2009).

3. Duzgoren-Aydin N.S., Sources and characteristics of lead pollution in the urban environment of Guangzhou. Science of the Total Environment, 385: 182-195 (2007).

4. Jiries A.G., Chemical Evaluation of Treated Sewage Effluents in Karak Province and its Suitability for Irrigation Purposes. Pakistan Journal of Biological Sciences, 4: 1400-1402 (2001).

5. Akan J.C., Moses E.A. and Ogugbuaja V.O., Determination of Pollutant Levels in Mario Jose Tannery Effluents from Kano Metropolis, Nigeria. Journal of Applied Sciences, 7(4): 527-530 (2007).

6. Singh R, Verma R.S, Yadav Y. Use of Industrial
Wastewater for Agricultural Purpose: $\mathrm{Pb}$ and $\mathrm{Cd}$ in Vegetables in Bikaner City, India. Current World Environment, 7(2): 287-286 (2012).

7. Sarker B.C., Basak B. and Islam M.S., Chromium Effects of Tannery Waste Water and Appraisal of Toxicity Strength Reduction and Alternative Treatment. International Journal of Agronomy and Agricultural Research, 3: 23-35 (2013).

8. Hoque A. and Clarke A., Greening of industries in Bangladesh: pollution prevention practices. Journal of Cleaner Production, 51: 47-56 (2013). doi:10.1016/j. jclepro.2012.09.008

9. Chindah A.C., Braide A.S. and Sibeudu O.C., Distribution of hydrocarbons and heavy metals in sediment and a crustacean (shrimps- Penaeus notialis) from the bonny/ new Calabar river estuary, Niger Delta. African Journal of Environmental Assessment and Management, 9: 1-14 (2004).

10. Islam M. M., Mahmud K., Faruk O. and Billah M. S., Textile dyeing industries in Bangladesh for sustainable development. International Journal of Environmental Science and Development, 2(6): 428-436 (2011).

11. Sultana Z., Ali M., Uddin M. and Haque 
M., Implementation of Effluent Treatment Plants for Wastewater Treatment, Journal of Environmental Protection, 4 (3): 301-308 (2013). doi:10.4236/jep.2013.43035

12. Talwar R, Agrawal S, Bajpai A, Malik S. Assessment of Concentration and Variations due to Seasonal Effect on the Presence of Heavy Metals in the Water of Upper Lake, Bhopal. Current World Environment, 9(2): 421-425 (2014).

13. Malarkodi M., Krishnasamy R., Kumaraperumal R. and Chitdeshwari T., Characterization of heavy metal contaminated soils of Coimbatore district in Tamil Nadu. Journal of Agronomy, 6(1): 147 (2007).

14. Odeigah C. and Osanyinpeju O., Genotoxic effects of two industrial effluents and ethyl methane sulfonite in Clarias lazera. Food and Chemical Toxicology, 33: 501-505 (1995).

15. Chan Y.K., Wong C.K., Hsieh D.P.H., Lau T.K. and Wong P.K., Application of a toxicity identification evaluation for a sample of effluent discharged from a dyeing factory in Hong Kong. Environmental Toxicology, 18(5) 312-316 (2003).

16. Lah B, Gorjane G., Nekrep F.V. and Marinsek L.R., Comet assay of waste water geno-toxicity using yeast cells. Bulletin of Environmental Contamination and Toxicology, 72: 607-616 (2004).

17. Smolders R., Bervoets L. and Blust L., In situ and laboratory bioassays to evaluate the impact of effluent discharges on receiving aquatic ecosystems. Environmental Pollution, 132(2): 231-243 (2004).

18. Banglapedia, National Encyclopedia of Bangladesh, Asiatic Society of Bangladesh (2008).

19. APHA (American Public Health Association), Standard Methods for the Examination of Water and Wastewater, 19 ${ }^{\text {th }}$ Ed. Washington DC, p: 1019 (1995).

20. Ayers R.S. and Westcot D.W., Water Quality for Agriculture (FAO irrigation and drainage paper), 29: 4096 (1985).

21. Ayers R.S. and Westcot D.W., Water Quality for Agriculture (FAO irrigation and drainage paper), 29: 81 (1976).

22. Meade J.W., Aquaculture Management, CBS Publishers \& Distributors, New Delhi, India, p: 9 (1998).

23. DoE (Department of Environment), Report on the environmental quality standards for Bangladesh, Ministry of Environment, Dhaka 1000, Bangladesh (1991). 